\title{
EL RISCO DE LA DIVINA PASTORA DE CANTILLANA (SEVILLA): PERVIVENCIA, ESTÉTICA Y SIMBOLISMO DOCTRINAL DE UNA ESCENOGRAFÍA SACRA DEL BAJO BARROCO
}

\author{
THE RISCO OF CANTILLANA'S DIVINA PASTORA \\ (SEVILLE): SURVIVAL, AESTHETICS AND ALLEGORICAL \\ DOCTRINAL CONTENT OF A SACRED SCENERY \\ FROM BAROQUE ORIGIN
}

\author{
Juan Manuel Daza Somoano \\ IES Carmen Laffón, Sevilla. España \\ juanmanueldaza@telefonica.net
}

El risco es una escenografía sacra efímera, destinada al culto, que se instala cada año en la localidad de Cantillana con motivo de sus festividades marianas. Data del siglo XVIII y posee un hondo significado doctrinal y alegórico de raíz tardobarroca, que se analiza en el presente estudio.

Palabras clave: risco; Cantillana; escenografía sagrada; contenido alegórico-doctrinal; Barroco.

The risco is a sacred and liturgic ephimeral scenery which is set up annually in Cantillana town (Seville) for the Marian religious festivities. It comes from $18^{\text {th }}$ century and has a deep allegorical doctrinal content from Baroque origin.

Keywords: risco, Cantillana; sacred scenery; allegorical doctrinal content; Baroque.

\section{INTRODUCCIÓN}

El día 8 de septiembre, festividad litúrgica de la Natividad de la Virgen, destaca especialmente en el calendario devocional de Cantillana (Sevilla) desde antiguo: el Rosario de la Divina Pastora de las Almas, establecido en la iglesia parroquial de la villa desde su fundación en el siglo XVIII, celebra en esa fecha 
su fiesta mayor, cuyos puntales son la función principal de su instituto y la procesión nocturna con la imagen dieciochesca de la Virgen (Figura 1). Con ocasión de estos cultos principales anuales - a los que se unen el novenario en honor de la Divina Pastora y dos rosarios femeninos públicos a la manera del siglo XVIII, presididos por el simpecado de gala-, la congregación realiza el día 31 de agosto un solemne traslado de su imagen, sus reliquias y sus insignias desde el camarín de su capilla propia, situada en la nave de la epístola, hasta la capilla mayor del templo, pues es precisamente en esa ubicación donde tienen lugar la novena y la función principal. Cuando se realiza dicha traslación corporativa, en el presbiterio de la parroquia ya está instalado lo que se conoce popularmente en Cantillana como el risco, a la espera de que la hermandad, para culminar de manera ritual y expresiva la procesión claustral del traslado, proceda a entronizar en él a la Divina Pastora y a exponer a los pies del mismo sus insignias históricas -simpecado de gala, cruz y faroles procesionales, estandarte, banderas, etc.--

Una de las principales singularidades de todo este aparato ceremonial y cultual es sin duda ese altar de cultos llamado risco, cuya historia y significado requieren una pausada explicación, ya que sus rasgos se alejan considerablemente de los montajes convencionales que elabora la inmensa mayoría de las hermandades y cofradías con motivo de sus oficios litúrgicos.

\section{EL RISCO: RASGOS ESTÉTICOS Y TEATRALIDAD SAGRADA}

Como ya ha quedado apuntado, el risco es una escenografía sacra que cada año actúa como altar de cultos efímero para la devota imagen de la Divina Pastora de las Almas de Cantillana, venerada desde el siglo XVIII en la iglesia parroquial de este municipio sevillano. Puede decirse grosso modo que el montaje simula una montaña - de ahí su denominación popular ${ }^{1}$-, efecto conseguido fundamentalmente por una artificiosa combinación de corcho y vegetación naturales, junto a flores contrahechas, en cuya cima se sitúa el simulacro mariano, sentado bajo un rosal o un almendro y rodeado por numerosas ovejas de talla que pueblan las faldas del collado. A primera vista, lo más llamativo del montaje son sus grandes dimensiones, pues abarca desde el suelo del presbiterio hasta la bóveda de la capilla mayor, de la que cuelga el enorme lienzo pictórico que sirve de fondo a toda la escena, por lo que la altura total del risco ronda los quince metros, mientras que su anchura está en torno a los nueve.

${ }^{1}$ El DRAE define la palabra risco como "peñasco alto y escarpado, difícil y peligroso para andar por él". Es muy significativa esta definición académica y habré de recuperarla luego por sus implicaciones en el contenido doctrinal del risco de Cantillana, que será explicado en otro epígrafe del presente estudio. 
El referido paño o lienzo ${ }^{2}$, que vela por completo el altar mayor de la parroquia y transforma así notablemente el espacio y la percepción de la capilla mayor, representa un paisaje, entre real e idealizado, ambientado en las inmediaciones de Cantillana: arriba, se abre el cielo con un sutil celaje quebrado en luz por la manifestación, sobre una mandorla de fuego, de la paloma del Espíritu Santo, que derrama sus siete dones en forma de haz luminoso sobre la imagen de la Virgen, y bajo el ave de la Trinidad, un corro de ángeles infantes portan una corona de rosas encarnadas y descienden hasta la Pastora para ceñirla a su frente; uno de los querubes hace ondear una filacteria donde puede leerse esta invocación del Cantar de los Cantares: “¡Oh, Tú, la más hermosa de las mujeres, pastorea a tus ovejas!". Más abajo, recortadas en el horizonte ceniciento y cárdeno de la Sierra Morena, y contempladas desde levante en dirección a poniente, aupadas en lo más alto del alcor donde se asienta el caserío de Cantillana, alzan su silueta la torre y fábrica de la iglesia parroquial, a cuyas plantas se derraman en suave pendiente las cales y los tejares del pueblo.

En este telón aparece pintado asimismo el río Guadalquivir discurriendo por su antiguo cauce, que lindaba con la Alameda de los barqueros y circundaba el característico barranco que sirve de pedestal a la parroquia; la corriente de agua serpentea en perspectiva entre las verdes frondas de las márgenes y los tonos terrizos de unos intuidos campos de labor, en cuyo primer término se inclina una parda roqueda ribeteada por un cañaveral y una hilera de adelfas y retamas, mientras que en su centro crecen un manchón de pitas y tres chopos esbeltos y sinuosos. Las copas de estos árboles se mimetizan, en una lograda ilusión óptica muy barroca y teatral-, con las ramas naturales de álamos que lucen en ese flanco del risco, de manera que lo pintado parece salir del cuadro para metamorfosearse en algo real y tangible.

${ }^{2}$ El que se usa hoy fue estrenado en 2007 y es obra del pintor cantillanero Juan Palomo Reina, profesor de la Facultad de Bellas Artes de la Hispalense. En los siglos anteriores, el risco ha llegado a tener hasta tres lienzos diferentes: el primigenio representaba un cielo azul tachonado de estrellas; el segundo, obra del afamado pintor costumbrista José Jiménez Aranda, suegro del pintor cantillanero Ricardo López Cabrera, reflejaba un paisaje de gusto romántico, arbolado y surcado por riachuelos, y fue colocado por primera vez en 1900, coincidiendo con la trascendental participación del cardenal Marcelo Spínola en las fiestas mayores de la Divina Pastora (vid. ARIAS SOLÍS, Florencio: La Divina Pastora de Cantillana y el Cardenal Spínola. Cantillana, 1987; entre otras cosas, este opúsculo transcribe el sermón leído por el beato Spínola en la función del 8 de septiembre y relata cómo se produjo la concesión por parte del prelado de la autorización para labrar la capilla y el camarín actuales de la Virgen, propiedad de la hermandad); el tercero e inmediatamente anterior al actual se ejecutó en 1983 por parte de los cantillaneros Francisco Rodríguez Lobo y Antonio Solís Sáez de Tejada, siguiendo una línea y estilo similares al lienzo de Jiménez Aranda. 
Este lienzo actúa como una suerte de trampantojo campestre que otorga sensación de profundidad y contextualiza en un entorno afín el escenario que tiene justo delante, que no es otro que el risco propiamente dicho, esto es, el monte simulado que preside la imagen mariana. Al ver la conjunción de ambos elementos, la impresión general es de estar contemplando una gran peña verdecida y floreada, un espacioso paraje natural con un marcado cariz bucólico muy en consonancia con la advocación de la Virgen, representada iconográficamente como una pastora -cayado, sombrero, pellica- que apacienta su rebaño esparcido por las laderas y vaguadas del promontorio. Tal figuración agreste se logra con la yuxtaposición de grandes paneles de corcho de alcornoque, cuya aspereza montaraz queda atemperada, refrescada, con la intercalación de vegetación autóctona recién cortada -fundamentalmente lentisco, acompañado de romero, juncia, palmas, aloes, etc. - y el colorido de las flores contrahechas ${ }^{3}$-rosas, sobre todo- y naturales que se colocan aquí y allá.

La teatralidad de toda esta tramoya enramada es notable, porque el locus resulta muy acorde con el oficio desempeñado por el personaje principal de la escena -la Virgen pastora, que se inserta con fluidez en el medio y discurso pastoril que la rodea-y porque el paisaje representado sobrecoge e interpela, haciendo partícipe de su cifrado y su mensaje al espectador/fiel, en tanto en cuanto este lo percibe como muy verosímil, convincente y rotundo. No en vano, el risco está elaborado con materiales muy efectistas y reconocibles -por tradicionales, cotidianos y populares-, cuya fuerza sugestiva se amplifica además con el ajuar suntuario de que dispone la hermandad para su exorno: cuatro añejos candelabros de guardabrisas en plata ascienden simétrica y piramidalmente hacia la cúspide -hacia la Pastora, por tanto-proyectando su luz eléctrica sobre el altar y sobre el conjunto escultórico formado por la Virgen y tres ovejas ${ }^{4}$; la

${ }^{3}$ La artesanía de las flores manufacturadas cuenta con una gran tradición en la estética de los cultos pastoreños de Cantillana. Se utilizan desde antiguo, por ejemplo, para elaborar árboles artificiales -almendros y rosales, principalmente-, injertando dichas flores en troncos y ramas naturales, que se forran a mano con papel de seda verde u ocre oscuro. Esos árboles contrahechos, que encierran una peculiar simbología (vid. infra), cobijan a la Virgen en el risco, en su camarín y en la peña del paso procesional, además de aderezar diversas zonas del altar de la novena.

${ }^{4}$ El grupo escultórico primitivo de la Divina Pastora fue concebido en el siglo XVIII como una composición repleta de contenidos, formada por la imagen de la Virgen, el Cordero Inmaculado y Apocalíptico -icono de Cristo-, San Miguel Arcángel y tres ovejas más, que representan a la grey mística de la Iglesia en su triple dimensión de Pueblo de Dios triunfante, purgante y militante, respectivamente; el arcángel y las tres últimas ovejas citadas fueron destruidas durante el saqueo e incendio de la parroquia en 1936 -asalto del que fueron salvadas providencialmente la talla de la Pastora y la denominada popularmente "oveja de la mano" por la intervención heroica de un hermano ilustre, apodado $E l$ Borro. Vid. todos los detalles de este lance en DAZA SOMOANO, Juan Manuel y LÓPEZ 
iluminación general queda reforzada asimismo con apliques y antiguas lámparas de araña de gran formato descolgadas desde el techo; las cuatro piezas cuadrangulares que configuraban la canastilla del antiguo paso procesional, obra en metal plateado de finales del siglo XIX con una gran solera, se disponen alineadas en el arranque inferior del risco y le sirven de estrado; en la parte central, muy cerca de la mesa de altar y flanqueado por un juego de candeleros y ánforas de plata con flores de talco, se coloca un manifestador del mismo metal, obra de Esquembre en 1940, para la exposición del Santísimo Sacramento ${ }^{5}$, enriquecido en época moderna con guirnaldas de orfebrería basadas en motivos eucarísticos como la espiga y la uva; el ara donde se oficia la eucaristía queda revestido con un valioso frontal en plata de ley y estilo neoplateresco, labrado en 1951 por Seco Velasco; en los pilares del arco toral de embocadura al presbiterio, aparecen cuatro pedestales de plata y latón dorado, con labores de fundición y repujado, para sostener otras tantas jarras plateadas con ramos de flor cortada. Hay, en fin, en el risco una peregrina combinación de lo natural y lo artificial, de lo fresco y lo confeccionado, que a buen seguro ya estaba presente en sus comienzos y que sin duda constituye una de sus señas de identidad más representativas desde el punto de vista artístico y sensorial ${ }^{6}$.

HERNÁNDEZ, Antonio: "La devoción a la Divina Pastora de Cantillana durante la II República y la Guerra Civil", en Actas de las II Jornadas de Historia sobre la Vega del Guadalquivir. Edad Contemporánea. Sevilla, 2007, pp. 269-278-, pero durante la primera década del siglo XXI, la hermandad decidió con buen criterio recuperarlos y restaurar la inveterada estampa de la Virgen rodeada por ovejas de diversa índole y con San Miguel a su izquierda. El escultor y ceramista cantillanero Luis Manuel López Hernández fue el encargado de realizar las nuevas esculturas entre 2007 y 2009, además de una labor previa de documentación gráfica y diseño para conseguir una reproducción muy fiel de las piezas antiguas perdidas.

${ }^{5}$ Hasta los años treinta del siglo XX, en el risco se utilizaba como manifestador eucarístico un gran dosel de inspiración rocalla, colocado sobre una nube con ángeles que campeaba por encima de la imagen de la Divina Pastora (Figura 2). Las reformas litúrgicas de entonces, que desaconsejaron la exposición del Santísimo en lugares demasiado inaccesibles o extraños, dieron lugar a que desapareciera del risco aquel característico y llamativo dosel del manifiesto.

6 Vid. las figuras 3 y 4, en las que pueden observarse algunas panorámicas del aspecto actual del risco; en la figura 5, una instantánea del risco datada a mediados del siglo XX. Más fotografías de este montaje, con variada cronología y apostilladas por comentarios referentes a la historia material y el anecdotario del risco, en ARIAS SOLÍS, Florencio y DURÁN GALLARDO, Francisco Manuel: Pastora de Cantillana. Memoria gráfica de una devoción. Sevilla, 2001, pp. 23, 36, 39, 44, 119, 128 y 159. Esta misma obra cuenta con múltiples fotografías del "risco vicario", esto es, de la peña que siempre ha tenido el paso procesional de la Virgen (Figura 8), la cual es todo un risco en miniatura: vid. BARRANCA DAZA, José Manuel: "El paso de la Divina Pastora de Cantillana", artículo 


\section{EL RISCO COMO MANIFESTACIÓN PARADIGMÁTICA DEL ESPÍRITU TARDOBARROCO}

Pero el risco trasciende su emotividad teatralizante y lo puramente estético, pues, según explicaré con detalle más tarde, su principal fundamento es articular visualmente la alegoría del pastorado mariano tal como lo concibió y promulgó su ideólogo, el capuchino fray Isidoro de Sevilla (1662-1750). Para entender de manera cabal ese propósito es imprescindible hacer un poco de historia y partir del carácter puramente barroco del risco, que recoge de la religiosidad barroca el gusto por la catequización plástica, por el uso de lo visual y lo sensible como instrumento conativo y aleccionador ${ }^{7}$. Y es que el origen de este tipo de montajes estuvo unido a la aparición en 1703 de la advocación para la que fueron específicamente diseñados: el título mariano de Divina Pastora de las Almas, que nace y se desarrolla bajo las coordenadas culturales y religiosas del Barroco dieciochesco, según las disposiciones de fray Isidoro de Sevilla, a quien se debe la concepción y argumentación libresca de esta iconografía de la Virgen -netamente sevillana- para convertirla en eficaz herramienta de evangelización a través de las misiones populares capuchinas ${ }^{8}$.

En el caso de la propia configuración estética de la nueva iconografía, de su primera presentación pública y de los métodos pastorales de difusión e implantación de la misma, son claramente reconocibles las huellas de la sensibilidad y los mecanismos propagandísticos barrocos. La representación iconográfica de la Virgen como pastora, por ejemplo, fue sometida por fray Isidoro a una profunda sistematización ${ }^{9}$, imbricada a todas luces en las polémicas doctrinales de la época como vía de confrontación ${ }^{10}$ y deudora, sobre todo, del código estético y cultural del bucolismo, que se erige como uno de los registros más pujantes de este

de investigación publicado en la web: http://www.lahornacina.com (Consultado el 12-92017).

7 Vid. MARAVALL, José Antonio: La cultura del Barroco. Análisis de una estructura histórica. Barcelona, 2008; en especial la cuarta parte y el apéndice de este tratado clásico sobre la cosmovisión barroca y sus derivaciones pragmáticas.

${ }^{8}$ Contamos en la actualidad con una exhaustiva, documentada y lúcida monografía sobre el contexto histórico-cultural, antecedentes, fundamentos y hondura exegética de esta advocación, ilustrada además con un nutridísimo corpus fotográfico y bibliográfico: ROMÁN VILLALÓN, Álvaro: La Divina Pastora en los escritos de fray Isidoro de Sevilla (1662-1750). Sevilla, 2012. La consulta de esta obra enciclopédica resulta inexcusable para comprender en toda su profundidad el fenómeno religioso del pastoreñismo.

9 ROMÁN VILlalón, Álvaro: La Divina Pastora..., op. cit., pp. 535-576.

${ }^{10}$ Fray Isidoro quiso imprimir a la nueva advocación el prurito de antídoto o contrapunto a ciertas corrientes teológicas controvertidas y/o heterodoxas que estaban en discusión a comienzos del siglo XVIII, principalmente contra el jansenismo. Vid. ROMÁN VILlALÓN, Álvaro: La Divina Pastora..., op. cit., pp. 69-97. 
periodo y de todo el Siglo de Oro español ${ }^{11}$. Es por ello que ese naturalismo edénico que respira la red iconológica de la advocación la hace entroncar con una invariante intelectual y artística muy sobresaliente del Barroco tardío, al tiempo que se revela como una de las grandes intuiciones de fray Isidoro.

Toda vez que fray Isidoro consolidó su ocurrencia y movió los resortes necesarios para propagarla con garantías, atinó de pleno con la estrategia desplegada para ello: en este sentido, el método elegido para la primera exposición pública de la advocación muestra su predilección por una práctica piadosa tan extendida en la época y tan genuinamente tardobarroca como los rosarios públicos ${ }^{12}$, pues el 8 de septiembre de 1703, el fraile vicentelo presenta ante los fieles a María "con traje y título" de Pastora mediante un lienzo encargado ex professo a Alonso Miguel de Tovar ${ }^{13}$, al que confiere un carácter procesional, pues es sacado a la calle a modo de estandarte o simpecado para presidir un rezo callejero del rosario que recorrió el barrio sevillano de la Feria, desde la parroquia de San Gil hasta la Alameda de Hércules. Allí, ante la muchedumbre reunida en el bulevar, fray Isidoro pronunció un sermón panegírico alusivo a la conveniencia y calado espiritual de aquella novedad iconográfica. Todas estas estrategias estaban, como se ve, muy en la línea de la carga de emotividad inducida y del carisma misional que poseyó en Sevilla la religiosidad popular setecentista ${ }^{14}$.

${ }^{11}$ RODRÍGUEZ DE LA FLOR, Fernando: "Arcadia y Edad de Oro en la configuración de la bucólica dieciochesca", Anales de Literatura Española, 2, 1983, pp. 133-153.

12 Tras la peste de 1649 y teniendo como claro antecedente las misiones jesuíticas sevillanas del padre Tirso González, señalado promotor del rosario, la profusión de procesiones públicas de rezo del rosario, presididas por un estandarte o simpecado, se reveló como un fenómeno masivo, fuertemente afianzado y omnipresente en la piedad popular del bajo Barroco en Sevilla -y Andalucía- a partir de 1690, año en que, bajo el auspicio de los dominicos -en especial, fray Pedro Santa María de Ulloa-, inició esta costumbre la hermandad hispalense de la Virgen de la Alegría, de la parroquia de San Bartolomé, en la Judería. Vid. un trabajo insoslayable al respecto como es el de ROMERO MENSAQUE, Carlos José: El Rosario en Sevilla. Devoción, rosarios públicos y hermandades (siglos XV$X X I)$. Sevilla, 2004.

${ }^{13}$ Es, al menos, la autoría que se ha venido repitiendo desde que lo dijera, sin aclarar la fuente, el historiador decimonónico Félix González de León en su Noticia artística, histórica y curiosa de todos los edificios... de Sevilla (1844). Vid. al respecto HERNÁNDEZ GONZÁLEZ, Salvador: "El pintor Alonso Miguel de Tovar y la hermandad de la Divina Pastora de Santa Marina", Boletín de las Cofradias de Sevilla, 535, 2003, pp. 607. 609; y GIRÓN MARÍA, Francisco: Alonso Miguel de Tovar: el pintor de la Divina Pastora. Huelva, 1988

${ }^{14}$ Esa confianza en la eficacia pastoral del rosario como vehículo para canalizar la piedad popular barroca, tan penitencial y exteriorizante, llevó a fray Isidoro a convertirlo en santo y seña de su actividad apostólica, que derivaba con frecuencia en la fundación de una hermandad o rebaño, fruto de una misión popular y entendida como medio duradero para la consolidación de la advocación y la extensión de su culto entre la gente del pueblo. 
Los riscos primitivos, que debieron de surgir al mismo tiempo que el culto -externo e interno- a la nueva advocación empieza a tomar carta de naturaleza, se inscriben, por tanto, en ese mismo clima piadoso y devocional, de manera que denotan también la influencia de unas tendencias y unos gustos, absolutamente barrocos, de los que son claro reflejo. Así, el risco de Cantillana, cuyos comienzos bien pudieron estar en relación con los primeros montajes de este tipo que se realizarían ${ }^{15}$, conserva todavía hoy esos rasgos barrocos que lo hacen inconfundible, porque, no en vano, y aunque carecemos de datos absolutamente objetivos que conviertan esta hipótesis en una certeza incontestable, el sentido común y algunos indicios documentales conservados inducen a pensar que el origen del risco cantillanero se remonta al siglo XVIII y que fue en esa centuria cuando comenzó a instalarse en su ubicación actual.

Primeramente, no se puede obviar, en este sentido, que las propias características materiales y conceptuales del risco, basado -insisto- en nociones genuinamente barrocas, acercan al siglo XVIII su proceso de nacimiento y consolidación, pero es que además esa circunstancia no puede ser desligada de la trayectoria histórica de la congregación que siempre ha sido la encargada de su montaje: el

Dichas congregaciones asumían sintomáticamente el rezo público del rosario o la corona franciscana como uno de sus fines esenciales y así se ha mantenido en algunos casos hasta la actualidad. El párrafo que se remata con esta nota, por cierto, no deja de ser una síntesis demasiado apresurada de la génesis de la advocación y sus pasos inaugurales. Para una panorámica mucho más exacta y analítica, vid. ROMÁN VILLALÓN, Álvaro: La Divina Pastora..., op. cit., pp. 307-347 y 579-873.

${ }^{15}$ Es probable que el propio fray Isidoro de Sevilla fuera el inspirador del montaje de los riscos pioneros, como el que instalaba ya en el siglo XVIII para su novena la Primitiva Hermandad de la Divina Pastora (vid., al respecto, MARTÍNEZ ALCALDE, Juan: Apuntes históricos y artísticos de la primitiva Hermandad de la Divina Pastora y Santa Marina. Sevilla, 2006; en las pp. 22 y ss. aparecen referencias documentales de los libros de cuentas que parecen demostrar que en 1714 ya se colocaba dicho risco), sita en la sevillana iglesia de Santa Marina y creada en 1703 por el venerable capuchino, que se convirtió en un carismático referente para la vida espiritual de la cofradía. A tenor de los testimonios gráficos conservados (Figura 7), la fisonomía de dicho altar a principios del siglo XX guardaba una gran similitud con el aspecto del risco de Cantillana por esas mismas fechas (Figura 2), por lo que no es descartable la influencia de uno sobre el otro. Quién sabe si ese influjo venía de muy antiguo y pudo estar favorecido por la posible presencia en Cantillana de fray Isidoro, pues siempre se ha especulado con la posibilidad de que fuera él quien instauró el Rosario de la Pastora en el municipio (vid. infra). Si bien este último extremo aún no ha podido probarse documentalmente, la verdad es que resulta bastante verosímil, teniendo en cuenta la intensa actividad misional de fray Isidoro en la provincia de Sevilla y, sobre todo, el parentesco de nuestro capuchino, por vía paterna, con los Vicentelo de Leca, que ostentaban el título de condes de Cantillana desde 1611. En aquel tiempo, esa dignidad nobiliaria recaía sobre Manuel de Baeza Vicentelo de Leca y Silva, que fue el IV conde y señor de la villa hasta mediados del siglo XVIII. 
Rosario de la Divina Pastora - germen de lo que después, tras la aprobación de unas reglas en 1805, se convirtió en la hermandad homónima que hoy conocemos- fue establecido en la iglesia parroquial de Cantillana sin lugar a dudas en el siglo XVIII, y posiblemente en un periodo temprano del mismo ${ }^{16}$; así se colige, sin dificultad y sin forzar interpretaciones, de muchos documentos de principios del siglo XIX estudiados por su descubridor, el historiador y antropólogo Antonio García Benítez" ${ }^{17}$ y de evidencias tan elocuentes como "las dos representaciones plásticas más antiguas de la advocación pastoreña en Cantillana, [que] son obras,

${ }^{16}$ Tradicionalmente se ha aceptado que el Rosario de la Pastora quedó instituido en 1720 y que fue el propio padre Isidoro el introductor de la devoción pastoreña en Cantillana, como ya he indicado. Esas referencias provienen de una noticia -no sabemos hasta qué punto acrítica o documentada en su momento- transmitida en el siglo XIX por el bibliotecario arzobispal José Alonso Morgado, quien en su obra Sevilla mariana, hablando de las fundaciones pastoreñas isidorianas, dice que "no menos célebre fue la de la villa de Cantillana, por los años de 1720, señalándose desde su instalación hasta nuestros días, por su fervor y entusiasmo religioso hacia la Divina Pastora, entre todas las demás que hay noticia”. Vid. ALONSO MORGADO, José: Sevilla mariana. T. III, Sevilla, 1882, p. 134. Desde la honestidad y el rigor historiográfico, las palabras de Morgado no son suficientes -aunque, a priori, tampoco sean automáticamente desechables- para afirmar que el Rosario de la Pastora fue fundado en dicha fecha, pero sí es cierto, y conviene tenerlo presente, que ese hito cronológico no solo no contradice en absoluto otras evidencias existentes, sino que encaja sin apenas reparos en la lógica de la secuencia histórica que de ellas se deduce, según explico en el párrafo de arriba y en la nota siguiente.

17 Aparecen transcritos e interpretados en Los manuscritos perdidos y hallados en $\mathrm{Pa}$ lacio. Orígenes históricos y vicisitudes emocionales de los rosarios de mujeres de Cantillana. Sevilla, 2013. Entre todos esos papeles, destaca especialmente una carta firmada por José Ortega en nombre de la que entonces era mayordoma del Rosario, Elena de la Barrera y Morales, escrita en septiembre de 1804 y dirigida al vicario del Arzobispado de Sevilla; allí se lee una declaración trascendental y sumamente aclaratoria sobre la antigüedad del Rosario de la Divina Pastora: "no hay en Cantillana quien se acuerde, ni hubiere conocido, el principio de la Congregación del Rosario con el título de María Santísima de la Pastora, colocada en su altar con bastante decencia en la iglesia parroquial, donde tiene dotada su fiesta el día del Patrocinio y que constantemente ha continuado hasta ahora, saliendo el Rosario en procesión durante todos los días de fiesta. [...] El establecimiento del antiguo Rosario en la iglesia parroquial [es] de tiempo inmemorial”. Vid. GARCÍA BENÍTEZ, Antonio: Los manuscritos..., op. cit., pp. 14 y 24. También sabemos fehacientemente gracias a estas misivas manuscritas que había existido, al menos, una mayordoma anterior a Elena de la Barrera y que el Rosario de la Pastora tuvo durante el siglo XVIII y parte del XIX dos cultos primordiales: el rezo público del rosario en los días festivos y una función en honor de la Virgen, que es descrita en otra carta de 1804 como "fiesta anual con sacramento y misa mayor, que [...] paga la hermandad del Santísimo", que dejó "dotada" la anterior mayordoma y que se celebraba el día del Patrocinio, en noviembre. Ibidem, p. 25. En su primera etapa, por tanto, el risco se montaría con ocasión de los cultos pastoreños que se celebraban en torno a la festividad del Patrocinio de María; posteriormente, en el primer 
sin duda, de la primera mitad del siglo XVIII. La primera de ellas es un lienzo oval que correspondería al primitivo simpecado fundacional, atribuido al pintor sevillano Bernardo Lorente Germán, que se ajusta a la recreación bucólica inspirada en las Madonnas de Rafael que inició Tovar, pero presentando corona y ángeles de plata dorada superpuestos que se ajustan a la más pura estética barroca del primer cuarto del siglo XVIII (Figura 6). La segunda corresponde a la talla en madera policromada que se venera en un camarín de la nave de la epístola de la parroquia, siendo considerada por algunos autores como obra del círculo de Francisco Antonio Ruiz Gijón"18 o del de Pedro Duque Cornejo.

De otro lado, hay que destacar, entre varias más del mismo tenor, dos informaciones recogidas en sendos inventarios de bienes de la hermandad de la Divina Pastora de Cantillana que se conservan en el archivo de la corporación ${ }^{19}$, datados en 1807 y en una fecha indeterminada entre 1805 y 1816, respectivamente, en los que constan como propiedades "ocho borregos más catorce bichos [serpientes]" destinados al montaje del risco, del mismo modo que se constata la existencia de faroles y ovejas utilizados para el aderezo de aquel, así como el coste de su instalación, "ciento cuatro reales de vellón"; todo lo cual vendría a indicar que se trataba de una costumbre consolidada y con cierta veteranía en la dinámica cultual de la congregación ${ }^{20}$. En cualquier caso y sea cual sea la respuesta a los interrogantes sobre su datación, lo que más interesa a nuestro propósito es destacar que después de 210 años -como mínimo- de existencia ininterrumpida, el risco de Cantillana ha logrado mantener un grado de autenticidad de época realmente sustancial y un indiscutible sello barroco. Y todo ello incluso en estos tiempos actuales, caracterizados por una galopante estandarización en el ámbito estético y artístico de las cofradías, circunstancia que hace aun más meritoria la pervivencia del risco tal como lo conocemos en pleno siglo XXI.

Podemos sintetizar así los caracteres barrocos que trasluce el risco:

1. Protagonismo de lo visual-figurativo como instrumento didáctico y aleccionador. En palabras de Maravall, "es propio de las sociedades en las que se desarrolla una cultura masiva de carácter dirigido, apelar a la eficacia de la imagen visual. El Barroco, por uno y otro lado, tenía que ser, pues, como

cuarto del siglo XIX, con el cambio de la función y la novena a septiembre, el risco pasaría a ser instalado en ese mes, como sigue ocurriendo hoy.

${ }^{18}$ MEJÍAS ÁlVAREZ, María Jesús: "Las joyas del siglo XVIII de la Pastora de Cantillana como elementos definitorios de su iconografía”, Laboratorio de Arte, 14, 2001, p. 276.

19 Archivo de la Hermandad de la Divina Pastora de Cantillana (AHDPC), leg. 12, carp. 1.

$20 \mathrm{Vid}$. otros datos significativos semejantes a estos, extraídos igualmente del archivo de la hermandad, en ARIAS SOLÍS, Francisco Javier: "El molino y la fuente del risco en la novena de 1853”, Cantillana y su Pastora, 18, 2013, p. 58. 
efectivamente fue, una cultura de la imagen sensible. [...] Utilizando los medios plásticos, la cultura del siglo XVII puede llevar a cabo, con la mayor adecuación, sus fines de propaganda; [...] es la vía calderoniana para hacer visibles, con toda la fuerza de lo patente que la visión alcanza, los principios y preceptos de las doctrinas [...]. El valor de eficacia de los recursos visuales es incontestado en la época" ${ }^{21}$. El Barroco seiscentista recogió con toda su vitalidad lo estipulado en el siglo XVI por el Concilio de Trento respecto a la idoneidad de los elementos visuales para catequizar al vulgo y hacer más inteligibles y convincentes los mensajes instructivos de la Iglesia en unos tiempos en los que la capacidad persuasiva se entendía como clave para frenar la heterodoxia y la agitación contestataria contra la oficialidad eclesiástica $^{22}$. La inercia de esa tendencia llegó aún con aliento al setecientos, y con más vigor, si cabe, tiñó la religiosidad sevillana dieciochesca, que conservó una marcada personalidad barroca hasta el último tercio del siglo XVIII. Pues bien, el risco supone una cristalización de algo tan barroco como esa expresión plástica de un concepto de fe, un principio doctrinal o un episodio bíblico para facilitar su intelección y asimilación por parte de los fieles: en este caso, el mensaje transferido son las complejas significaciones que encierra la advocación de la Divina Pastora, cuyos parámetros y plasmación en el risco explicaré en el epígrafe siguiente. Tiene el risco, por tanto, una dosis considerable de ese espíritu contrarreformista del que no pudieron sustraerse las manifestaciones artísticas barrocas de índole religiosa, supeditadas tantísimas veces al imperativo de que la imagen fuera el mejor recurso doctrinario.

2. Teatralización de lo sagrado. El cariz escenográfico del risco deriva del auge que experimentó en el Barroco la teatralidad, concepto que se aplicó con extraordinaria profusión y pragmatismo a todos los órdenes sociales y culturales ${ }^{23}$. Lo teatral conseguía, de nuevo, involucrar seductoramente al espectador/fiel en la escena -o en el misterio que se presentaba ante sus ojos, en el caso de los montajes o festejos religiosos- por medio de la creación de una falsa realidad, de una ficción gesticulante y vivificada que penetraba en el espacio y tiempo de lo real, para atrapar las voluntades de los observantes, que dejaban de serlo para mutarse en actores de algo que habían empezado a percibir y sentir como propio; sin olvidar que la aparatosidad y artificio que habitualmente se les conferían a estas

${ }^{21}$ MARAVALL, José Antonio: La cultura del Barroco..., op. cit., pp. 501-503.

22 SEBASTIÁN LÓPEZ, Santiago: Contrarreforma y Barroco: lecturas iconográficas e iconológicas. Madrid, 1981; en particular, el capítulo titulado "El arte al servicio del dogma".

${ }^{23} \mathrm{Vid}$. el clásico ensayo OROZCO DÍAZ, Emilio: El teatro y la teatralidad del Barroco. Madrid, 1969. 
escenografías, sacras o profanas, constituían una demostración de poder de las instancias jerárquicas. Como apunta Martínez Alcalde, "al sobrevenir el Barroco la liturgia religiosa recibe una indudable influencia escenográfica, cuyo máximo exponente estaría en esa liturgia callejera de las procesiones, tan arraigadas en nuestra Andalucía. No podemos olvidar tampoco los famosos autos sacramentales que se representaban con motivo de las fiestas del Corpus, sobre unos carros llamados rocas, donde imaginativamente debemos ver el más lejano y conspicuo antecesor de los riscos pastoriles" 24 . Está claro que el risco bebe de esa inclinación barroca hacia lo teatral-escenográfico, pues se configura como un escenario estático, pero provisto de dinamismo implícito y, sobre todo, de narratividad, en la medida en que se encuentra habitado por personajes a lo divino, coherentes con el medio que ocupan, que desempeñan su función dentro de él e interactúan entre sí. El resultado global envuelve al devoto y consigue hacerlo partícipe de lo que acontece dentro de la puesta en escena.

3. Psicologismo y aptitud apelativa. Todo lo expuesto en los dos puntos anteriores comparte un denominador común, como es su especial contribución a las tácticas barrocas de atracción y conmoción sensorial. La clásica dualidad horaciana del docere-delectare -enseñar y deleitar-, en que se cifraban desde antiguo los fines esenciales del arte en general, queda ampliada -cuando no sustituida- en el Barroco por el concepto de admiratio -admiración, asombro, desconcierto-: muchas figuraciones plásticas barrocas buscan sorprender al receptor y suspender su ánimo, porque se partía del convencimiento de que moviendo las pasiones y apelando a la sentimentalidad se conseguía un impacto suasorio inapelable. El risco participa de ese mismo impulso, máxime si consideramos que desde sus orígenes estos montajes, al igual que los retablos o algunas arquitecturas efímeras, están concebidos como apoyo gráfico de los sermones y predicaciones. "En los sermones - dice Maravall- llega a ponerse en uso servirse de jeroglíficos impresos o estampados, de pinturas a descifrar, que refuerzan la llamada que al espectador o al público que escucha se le dirige, abriendo cauce en su atención para la penetración de una doctrina o del sentimiento de admiración, de suspensión, de estupor, etc. que facilitarán la captación de ese público. [...] Por eso los hombres del Barroco saben que la visión directa de las cosas importa sobremanera. De ella depende que se enciendan movimientos de afección, de adhesión, de entrega. La presencia directa o, cuando menos, la de representaciones simbólicas, lo más fielmente unidas a la repetición de lo representado, tiene una fuerza

${ }^{24}$ MARTÍNEZ ALCALDE, Juan: "El Risco, una escenografía sagrada y bucólica", Cantillana y su Pastora, 8, 2003, p. 38. 
incomparable" 25 . Es esto, precisamente, lo que consigue el risco: hacer presentes ante el auditorio, mediante el simbolismo, las abstracciones de un sistema doctrinal, que pasan a ser signos tangibles capaces de interpelar desde la emoción.

4. Lo alegórico y lo aparente. Ambos son conceptos clave de la cosmovisión barroca del mundo y del $\operatorname{arte}^{26}$, y, a su vez, están presentes en el risco. La proliferación de libros de emblemas o el uso de esos mismos emblemas y de jeroglíficos en las arquitecturas efímeras religiosas o civiles, por ejemplo, son una muestra muy representativa de dicha tendencia conceptual y plástica, que se aplicó insistentemente como reclamo pedagógico ${ }^{27}$. Tal uso recurrente del símbolo y la alegoría en las artes barrocas proviene, entre otras cosas, de ese gusto, tan fructífero en la época, por el juego continuo entre apariencia y realidad: las alegorías son en muchas ocasiones el envoltorio que oculta tras de sí al naturalismo barroco y nos impele a hallar el mensaje escondido tras ese aparente realismo. Decía Góngora, el poeta barroco por antonomasia, para defenderse en 1615 de aquellos que condenaban su poesía mayor por tener como piedra angular la oscuridad verbal, que esta "da causa a que, vacilando el entendimiento en fuerza de discurso, trabajándole (pues crece con cualquier acto de calor), alcance lo que así en la lectura superficial de sus versos no pudo entender, luego hase de confesar que tiene utilidad avivar el ingenio y eso nació de la oscuridad del poeta. Eso mismo hallará Vm. en mis Soledades, si tiene capacidad para quitar la corteza y descubrir lo misterioso que encubren" 28 . Esa ardua operación de descifrado no solo desemboca en la intelección

${ }^{25}$ MARAVALL, José Antonio: La cultura del Barroco..., op. cit., pp. 502 y 505.

${ }^{26} \mathrm{Vid}$. las interesantes apreciaciones sobre el alegorismo barroco contenidas en BENJAMIN, Walter: Origen del drama barroco alemán. Madrid, 1990.

${ }^{27}$ No estará de más recordar cómo los emblemas se usaron durante el Barroco para divulgar los ideales contrarreformistas; vid. RODRÍGUEZ DE LA FLOR, Fernando: "La imagen del mundo: emblemática y contrarreforma", en Florilegio de estudios de emblemática. El Ferrol, 2004, pp. 65-80.

${ }^{28}$ La cita proviene de la Carta en respuesta que Góngora, o su círculo más cercano, difundió en 1615 para salir al paso de las agrias críticas recibidas tras la difusión manuscrita en 1613 de sus poemas mayores, el Polifemo y las Soledades, auténticos paradigmas poéticos del Barroco español. Vid. el texto completo de la epístola gongorina en DAZA SOMOANO, Juan Manuel: "Los testimonios de la polémica epistolar Lope-Góngora (1615-1616), con edición de la Respuesta de Góngora", en El Poeta Soledad. Góngora 1609-1615. Zaragoza, 2011, pp. 271-288. La carta de Góngora fue estudiada por VILANOVA, Antonio: "Góngora y su defensa de la oscuridad como factor estético", en Homenaje a José Manuel Blecua. Madrid, 1983, pp. 657-672; y DOMÍNGUEZ CAPARRÓS, José: "Razones para la oscuridad poética", Revista de literatura, LIV, 108, 1992, pp. 553 573. 
del mensaje, sino que conlleva un goce añadido que refuerza la empatía con lo expresado por dicho mensaje. El risco es en sí mismo una alegoría que invita a ser desentrañada o, si se quiere, una enigmática materialización plástica de la alegoría ideada por fray Isidoro para expresar su concepción del Pastorado mariano, para cuyo conocimiento y el de su presencia en el Risco remito a lo expuesto en el epígrafe siguiente.

5. Fisiocratismo y utopía arcádica. El risco -y la advocación que le da sentido- es una realización física, aunque ficcional, de una mentalidad que disfrutó de gran predicamento en el Siglo de Oro - especialmente en la literatura, ya desde el siglo XVI, con los libros de pastores, popularizados a partir de la Arcadia de Sannazaro, o con las églogas en verso, que vieron forjado su canon en la producción poética de Garcilaso de la Vega-y que llega briosa al siglo XVIII para decantarse en nuevos perfiles y matices: la recreación de lo edénico, de lo arcádico, a través de una estilización y sublimación de lo campestre ${ }^{29}$. Ello, que latu sensu podemos denominar bucolismo, pervivió en las artes dieciochescas por el indudable calado de su tradición milenaria, en general, y áurea, en particular, pero también por el advenimiento en el siglo XVIII de ciertas filosofías y corrientes de pensamiento como la fisiocracia, que defendían el valor intrínseco de la naturaleza y la agricultura como vías de sostenimiento ideales para el hombre y el estado. Añádase, asimismo, por su relación directísima con el Risco, que en el Setecientos fue habitual la teatralización de lo bucólico.

6. Sugestividad de lo efímero. Tratando de las arquitecturas efímeras para el culto divino y profano durante el Barroco hispalense, Lleó Cañal pone de relieve cómo lo efímero, arquetipo angular en la actitud barroca ante el mundo, esboza en el imaginario de la época la sombra de lo inconsciente durante la celebración de las fiestas urbanas, ya sean religiosas o regias ${ }^{30}$. El carácter efímero del risco, con toda su barroca fugacidad, parece entrar engañosamente en conflicto con la enjundia del mensaje que soporta y nos sitúa frente a la paradoja -tan escalofriante y tan barroca- de que, con su cíclica desaparición, desaparezca del mundo visible su contenido, el cual, sin embargo, ha podido alcanzar, gracias a esa provisionalidad,

${ }^{29}$ En realidad, el Siglo de Oro no hizo sino recoger una remota tradición literaria que se remonta al periodo helenístico, época en la que autores como Teócrito o Bion comienzan a codificar unos tópicos que después, en tiempos de la Roma imperial, serán recogidos y reelaborados de manera genial por Virgilio; esa trayectoria grecolatina recorre la Edad Media y llega hasta el Renacimiento para rejuvenecer y encajar en algunos engranajes de la modernidad naciente, como la vuelta al clasicismo o el humanismo cristiano.

${ }^{30}$ LLEÓ CAÑAL, Vicente: "De la arquitectura (efímera) considerada como una de las Bellas Artes", en Rito y Fiesta: una aproximación a la arquitectura efímera sevillana. Sevilla, 2004, p. 14. 
un "sueño o espejismo" de magnificiencia -mucho más difícil de conseguir en lo perdurable- que ha cumplido con su función sorpresiva y retórico-argumentativa ${ }^{31}$.

\section{EL RISCO: TRASUNTO VISUAL DE LA ALEGORÍA DEL PASTORADO MARIANO SEGÚN FRAY ISIDORO DE SEVILLA}

Demostrada la impronta barroca del risco, solo resta explicar someramente su denso entramado de significaciones, que supone una plasmación plástica del ideario de fray Isidoro. El núcleo del montaje, a saber, la imagen de la Virgen representada como Divina Pastora de las Almas, comporta ya por sí sola todo un cúmulo de símbolos iconológicos. Según fray Isidoro y por decirlo de una manera -advierto- que demasiado simple, si a María puede reconocérsele el oficio místico del pastoreo de las almas humanas, es, entre otras muchísimas cosas, porque como tal quedó designada en el Calvario por su hijo y por ser la madre de Jesucristo, el Buen Pastor, que en el Evangelio de San Juan se atribuye a sí mismo el carisma de esa conocida parábola, de la que surgió, ya en época paleocristiana, una próspera iconografía. Todo ello permite presentar a la Virgen ataviada como una pastora y colocarle, por tanto, ciertos atributos materiales consustanciales a dicho quehacer mundano, aunque, como es natural, aquellos van más allá de lo puramente denotativo, es decir, no son simples elementos de caracterización, sino que se dignifican o divinizan a través de la connotación simbólica.

Así, el cordero que acaricia la mano diestra de María no es sencillamente el animal que corresponde a su aparente menester rural, sino la figuración de Jesucristo como Cordero de Dios, el Cordero pascual y apocalíptico, la víctima a la que se refirieron Jeremías o Isaías y que propició con su sangre derramada en sacrificio la redención del género humano; la pellica no es una prenda de vestir propia de pastores sin más, sino una alusión a los vellones con que se cubría el Arca de la Alianza, icono judío veterotestamentario que se actualiza en la figura de la Virgen, metaforizada como el Arca de la Nueva Alianza por el misterio de la Encarnación; el cayado no es una mera herramienta de labriegos y ganaderos, sino memoria y presencia del bastón de Raquel, de la vara florecida de Moisés, del cetro del rey-pastor David, del vástago apacentador de los Salmos, emblemas todos ellos de la autoridad y los desvelos de Dios ante su pueblo; el árbol que cubre a la Virgen, que en Cantillana es normalmente un rosal o un almendro, no debe entenderse como algo pintoresco o como un lógico elemento más del paisaje natural que la imagen, por ser pastora, requiere a modo de contexto, sino como un

${ }^{31}$ Recomiendo, por su útil visión panorámica, la calidad de su poso y la excelencia de su prosa divulgativa, la lectura del artículo FARGA, Rosario: "El Barroco efímero: esplendor y decadencia”, Historias, 43, 1999, pp. 99-114. 
símbolo del acopio de oraciones - las rosas- ofrecidas por las ovejas a María, en el caso del rosal, o un emblema del Dios vigilante y centinela, alerta para cumplir sus promesas, si hablamos del almendro; etc. ${ }^{32}$.

Esa red simbólica se inserta en otra no menos rica y compleja: la expresada por la vasta montaña en cuya cúspide aparece sentada la celestial Pastora de las Almas en compañía del Cordero de Dios. El simbolismo de los montes como lugares de contacto con la divinidad aflora en muchos momentos relevantes de la historia de la salvación narrada por las Escrituras. La subida a la cima de un monte, la permanencia en ella en estado de oración o contemplación, auguran un trance epifánico, una decisiva irrupción de lo divino y lo sagrado en la esfera de lo terrenal, como leemos en los pasajes bíblicos del Monte Sinaí, del Tabor, de las Bienaventuranzas, de Getsemaní o del Calvario. El risco y su cumbre hacen presente a la divinidad, así como los escarpados caminos que median hasta ella. En lo más alto del risco, Madre e Hijo, Pastora y Cordero, irradian su majestad revestidos de gloria, al tiempo que invitan a emprender la necesaria subida a la puerta del redil eterno.

Pero esa ardua peregrinación ascensional debe tener unos protagonistas explícitos, sujetos a las incidencias y dificultades de cualquier itinerario vital. Por eso, el risco es también el "valle de abrojos", la "escalera entre flores y espinos que vincula la tierra y el cielo" 33 , que sus moradores se ven abocados a hollar. Las ovejas que habitan las faldas del monte representan a los seres humanos, a la grey mística de la Iglesia. Todas dirigen la mirada hacia la Virgen e imploran su auxilio ofrendándole las rosas -los avemarías- que llevan en la boca. Porque todas están en camino -la vida- y el sendero no es fácil ni llevadero: junto a la verdura, metáfora del pasto eucarístico a cuyo aprovechamiento nos urge la Virgen Pastora, crecen en el risco, con sus púas amenazantes, los cardos y las zarzas, que simbolizan los pecados, las tentaciones y los sinsabores de la existencia humana. Esos acechantes peligros para las ovejas -i. e., para los hombres- tienen en el risco otra elocuente y simbólica verificación, como son las serpientes, ancestral signo del

${ }^{32}$ Las limitaciones de espacio a que está sometido este estudio no permiten más prolijidad, sin duda necesaria, en la explicación de la iconología de la Divina Pastora de Cantillana, que se atiene con pulcra fidelidad a los estrictos y justificados cánones establecidos por fray Isidoro de Sevilla para la representación plástica de la advocación. Quedaron fijados principalmente en tres obras suyas, que llegaron a imprimirse: La Pastora Coronada (1705), La Mejor Pastora Asunta (1732) y El Montañés Capuchino y Misionero Andaluz. Vida del V. P. Fray Luis de Oviedo, Apostólico Misionero de la Divina Pastora (1742); la Orden los refrendó oficialmente en unas Actas Capitulares de 1742. Vid., al respecto, el análisis de ROMÁN VILLALÓN, Álvaro: "La imagen de la Divina Pastora de Cantillana. Estudio iconográfico, histórico, artístico, cúltico, difusivo, teológico e iconológico", Estudios franciscanos, 435, 2003, pp. 307-501, en especial las pp. 442-449 y 465-492.

33 Ambas son expresiones sacadas de dos coplas litúrgicas que se entonan en Cantillana durante la novena a la Divina Pastora. 
mal en la cultura judeocristiana y mediterránea, y un lobo que persigue -nuevo simbolismo- a una oveja descarriada o perdida. El mensaje que transparenta este lance está tomado directamente de las directrices dadas por fray Isidoro para representar la advocación, al igual que la figura del arcángel San Miguel, el Mayoral del rebaño, que aparece en el risco sobre un pequeño otero junto al lobo, con escudo y espada flamígera para ahuyentar a la alimaña ${ }^{34}$.

Lo dicho hasta aquí ya revela sobradamente la sofisticada alegoría que teje el risco en su conjunto. Pero hay más. No podemos dejar de señalar, por ejemplo, la aparición de algunos símbolos asociados a las letanías lauretanas, de gran tradición en la retablística y la pintura barrocas, en especial desde el estallido inmaculista $^{35}$. Y no es caprichoso que estén diseminados por diversos lugares de la montaña alegórica: tal disposición realza el cariz profundamente mariano del risco, apuntala el concepto de la Virgen en armonía con la naturaleza -con la Creación- y testimonia la omnipresencia de María, de su función mediadora, a lo largo de la vida. Así, un castillo o alcázar, policromado y estofado, que se eleva inexpugnable sobre un altozano, remite a la Virgen como plaza inaccesible para el pecado y como refugio de pecadores. Dos ángeles enarbolan un espejo y unas azucenas de plata, que evocan a María Inmaculada, prototipo de la pureza elegida y espejo de justicia. Una pequeña iglesia, con su campanil y su humilde cubierta a dos aguas, recuerda que la Divina Pastora es Madre de la Iglesia y templo del Espíritu Santo. Y aparte de estos signos de las letanías, hay que reseñar la concurrencia en el risco de algo tan profundamente simbólico como el pozo, que además de alabar a la Virgen como pozo de sabiduría lleno de la gracia divina, hace reparar de soslayo en la ausencia de un elemento que antaño tuvo el altar y que hoy ha desaparecido tristemente del mismo: el agua corriente ${ }^{36}$. Pues, en efecto, hay constancia documental de que antiguamente en el risco se disponían corrientes de agua, a modo de ríos, fuentes o manantiales, con toda la carga metafórica que ello entrañaba, ya que el agua representa el poder reparador y vivificador, la limpieza de espíritu, las esperanzas colmadas, la vida que discurre hasta desembocar en la muerte, en el caso de lo fluvial.

Fecha de recepción: 24 de octubre de 2017

Fecha de aceptación: 12 de abril de 2018

${ }^{34}$ Por todo lo expuesto en este párrafo, se entenderá que el risco no puede tener mejor nombre que el que posee, ya que la RAE define risco como: "peñasco alto y escarpado, difícil y peligroso para andar por él".

35 PEINADO GUZMÁN, José Antonio: "Simbología de las letanías lauretanas y su casuística en el arzobispado de Granada", en Lecciones barrocas: "aunando miradas". Córdoba, 2015, pp. 159-190.

${ }^{36}$ ARIAS SOLÍS, Francisco Javier: "El molino y la fuente del risco en la novena de 1853", op. cit. 


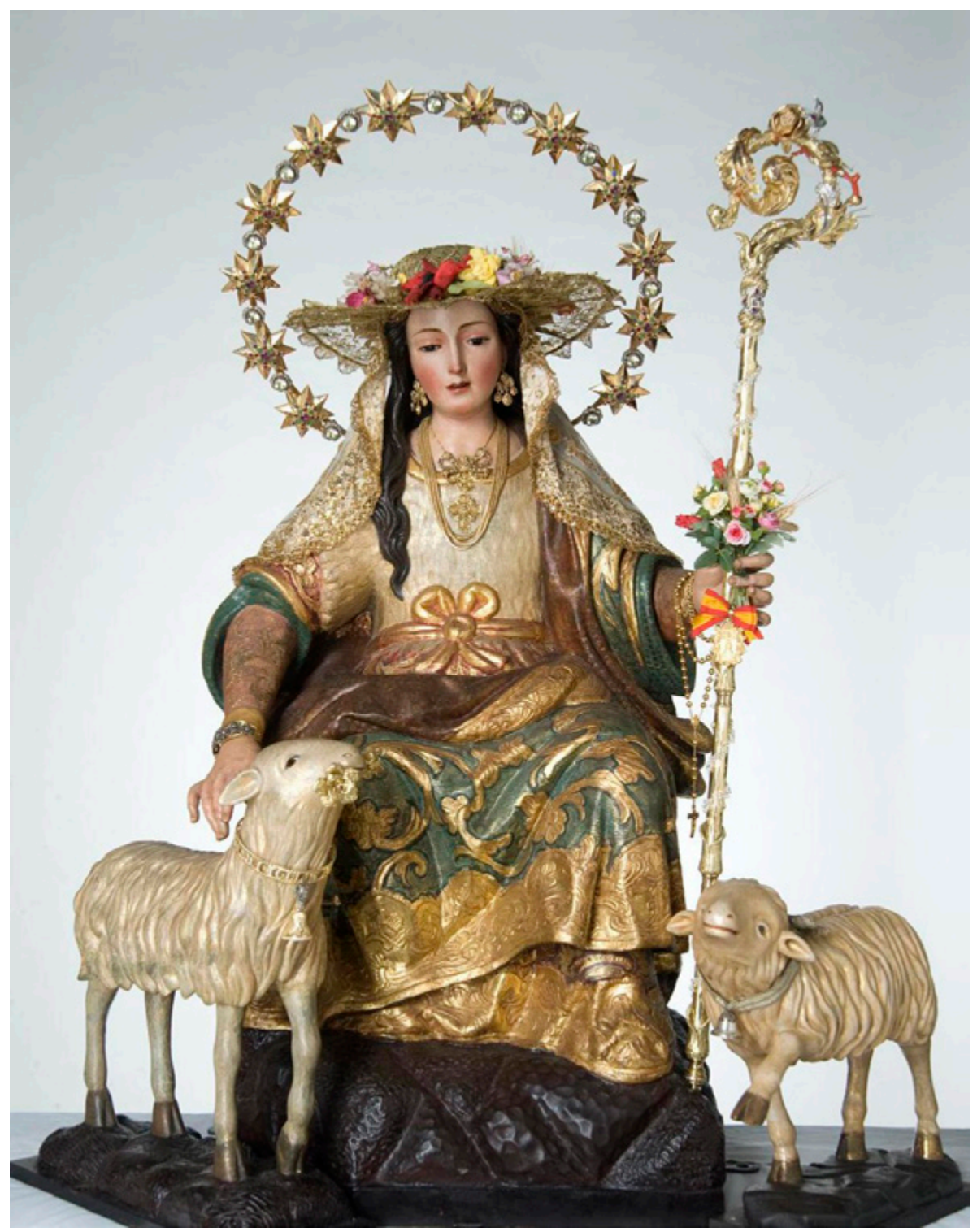

Figura 1. Anónimo, Divina Pastora de las Almas, primer cuarto del siglo XVIII, parroquia de Nuestra Señora de la Asunción, Cantillana (Sevilla).

Foto: Juan Carlos Gallardo. 


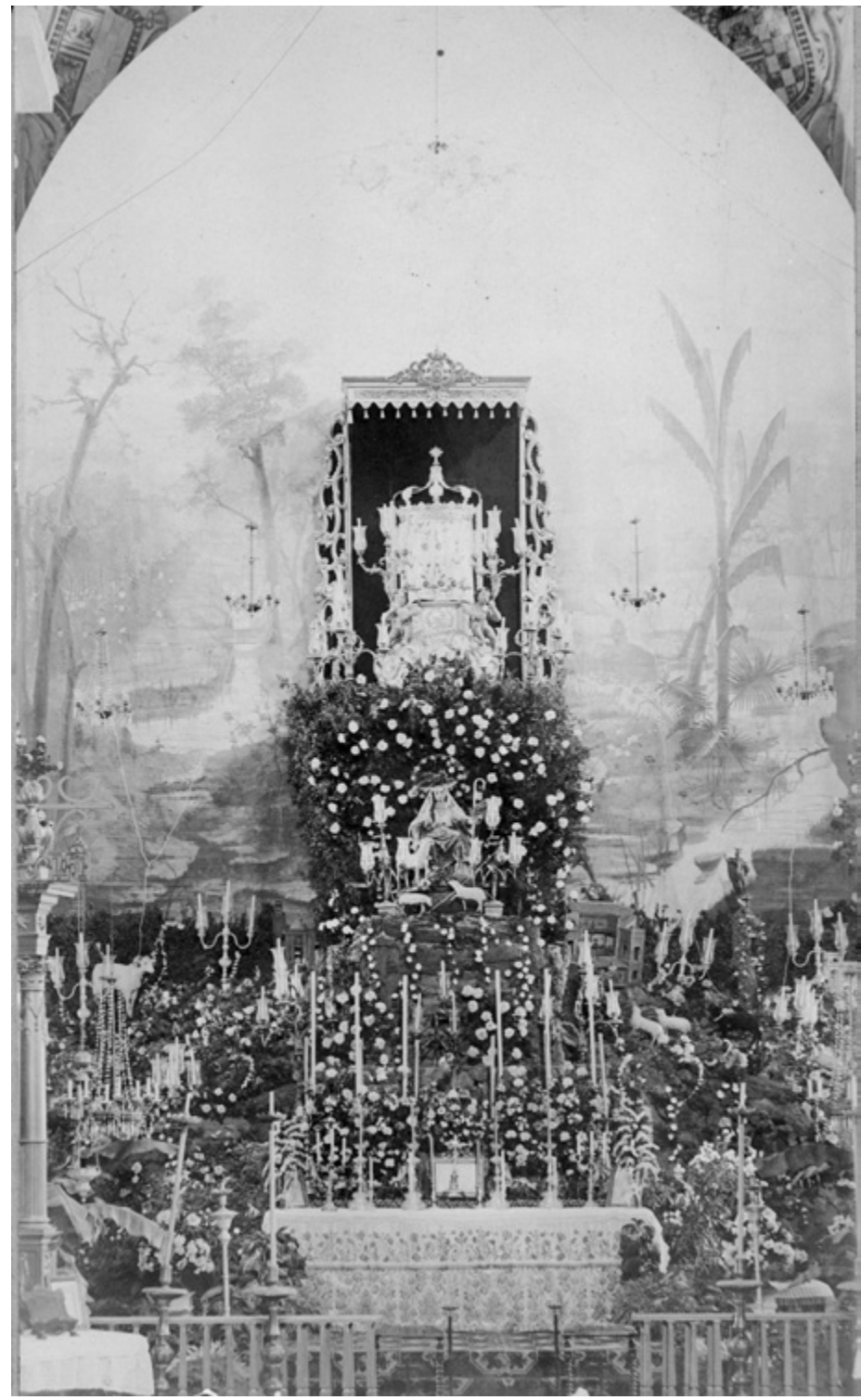

Figura 2. El risco de la Divina Pastora, 1912, parroquia de Nuestra Señora de la Asunción, Cantillana (Sevilla). Foto: Anónimo. 


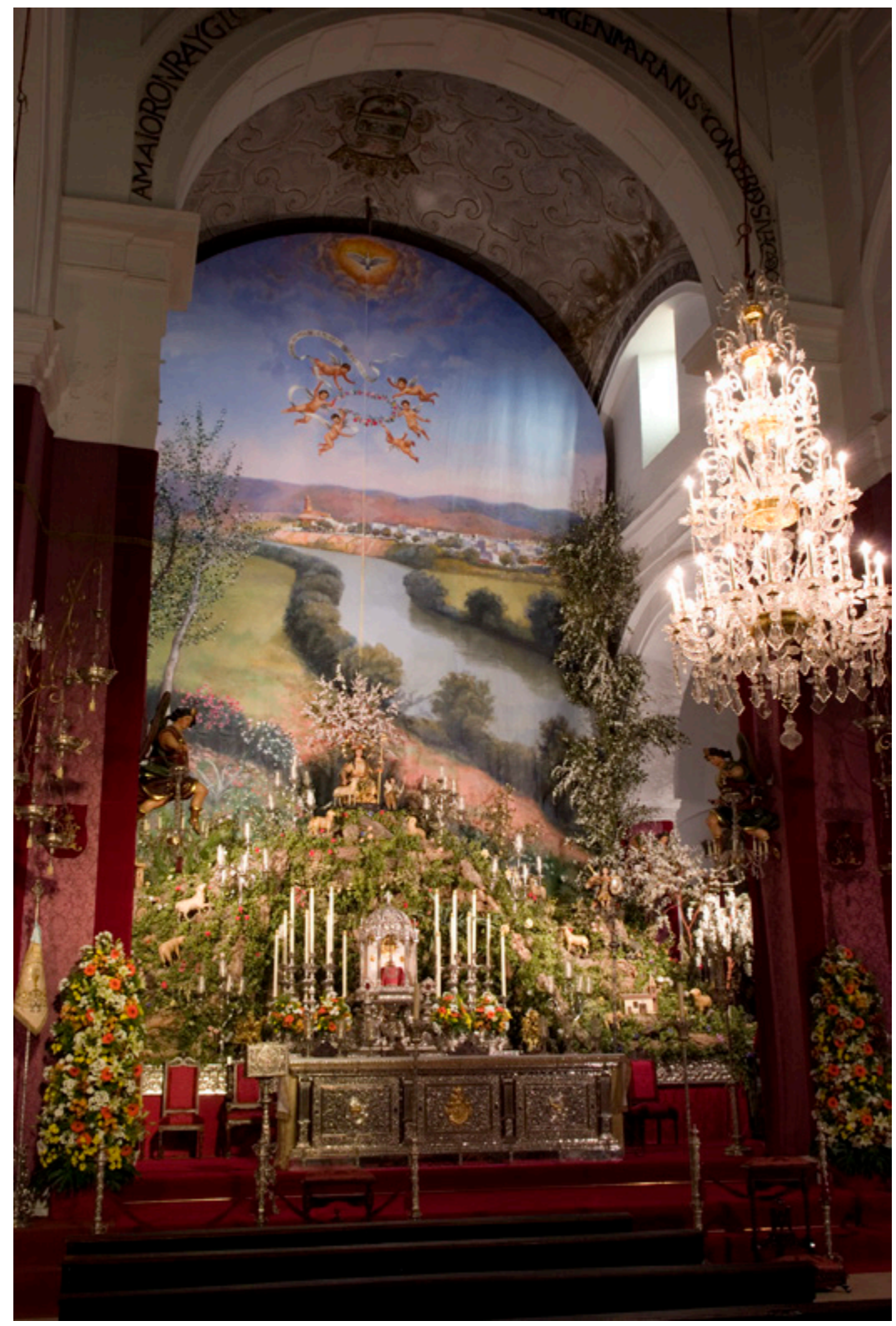

Figura 3. El risco de la Divina Pastora, 2007, parroquia de Nuestra Señora de la Asunción, Cantillana (Sevilla). Foto: Estudio imagen. 


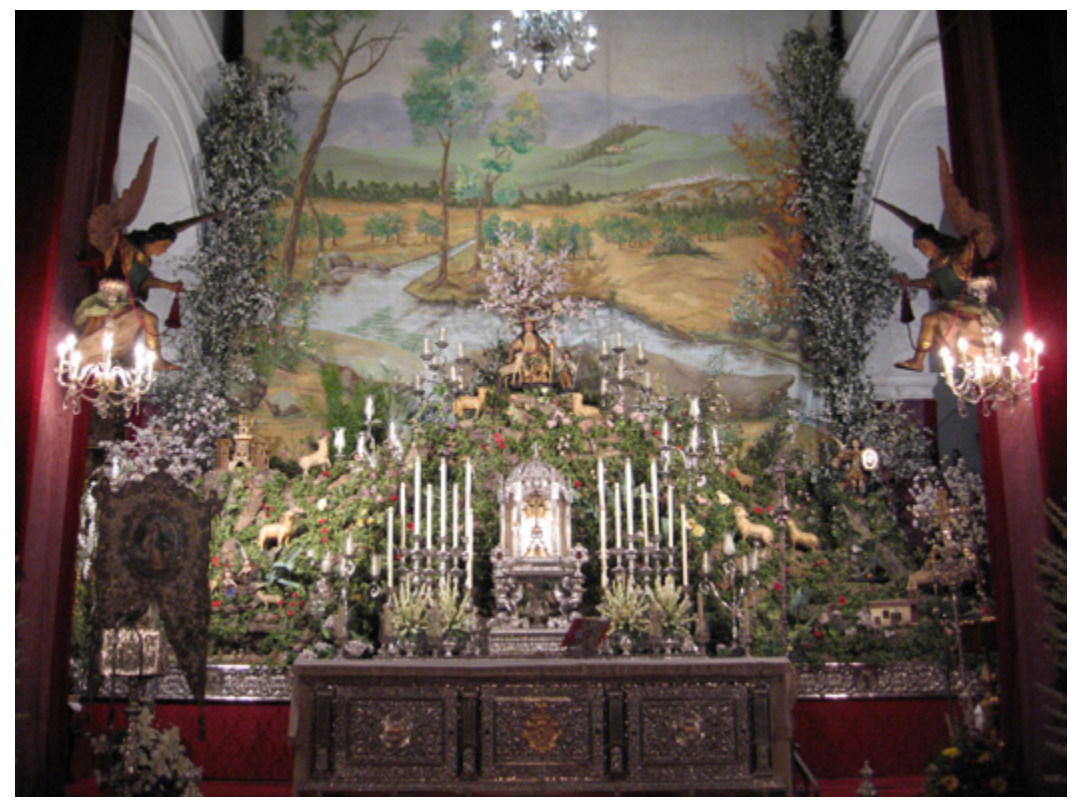

Figura 4. El risco de la Divina Pastora, 2006, parroquia de Nuestra Señora de la Asunción, Cantillana (Sevilla). Foto: Estudio imagen.

Figura 5. El risco de la Divina Pastora, mediados del siglo XX, parroquia de Nuestra Señora de la

Asunción, Cantillana (Sevilla). Foto: anónimo.

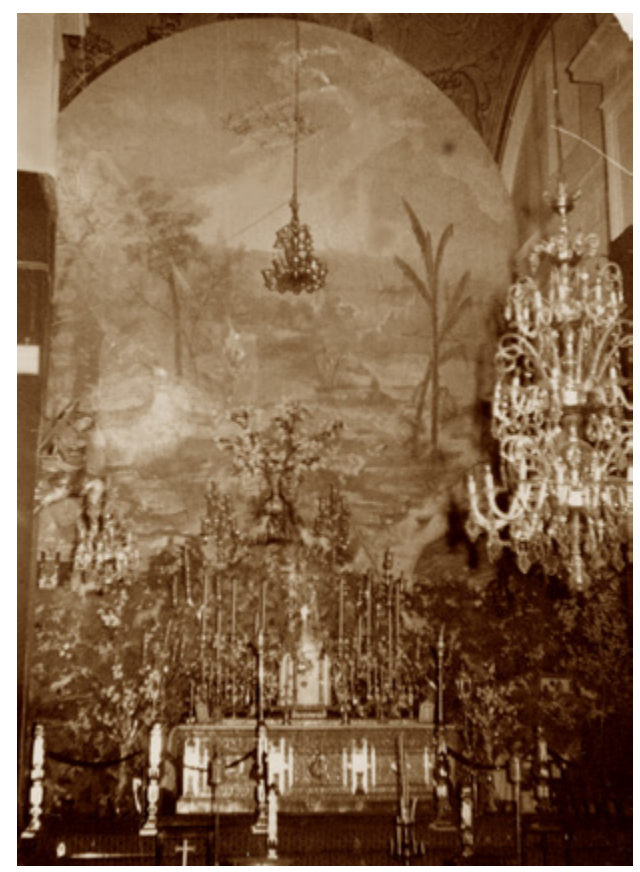

LABORATORIO DE ARTE 30 (2018), pp. 261-284, ISSN 1130-5762 e-ISSN 2253-8305 - DOI http://dx.doi.org/10.12795/LA.2018.i30.14 


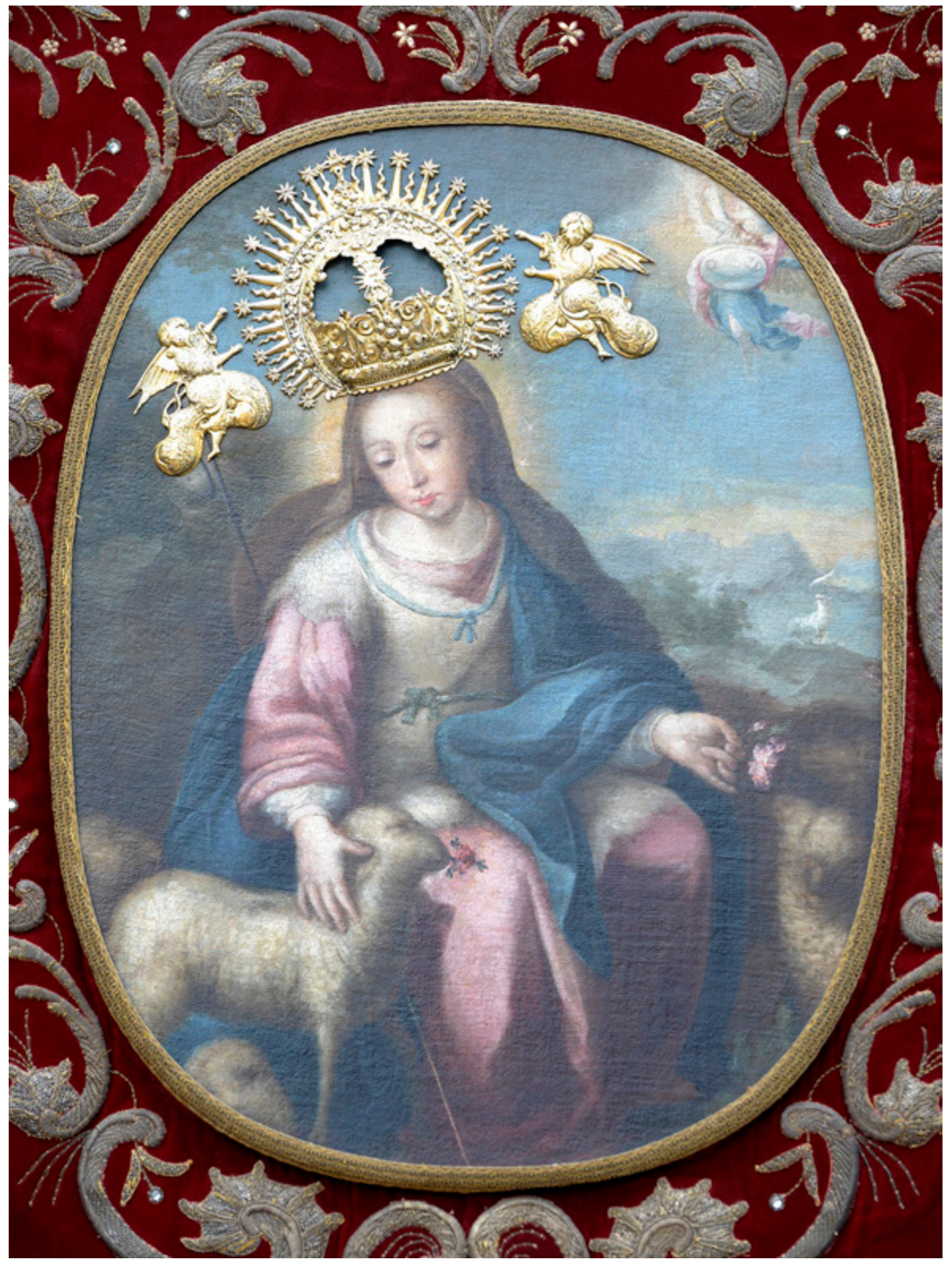

Figura 6. Bernardo Lorente Germán (atribución), Óvalo pictórico del simpecado fundacional del Rosario de la Divina Pastora, primer cuarto del siglo XVIII, parroquia de Nuestra Señora de la Asunción, Cantillana (Sevilla). 


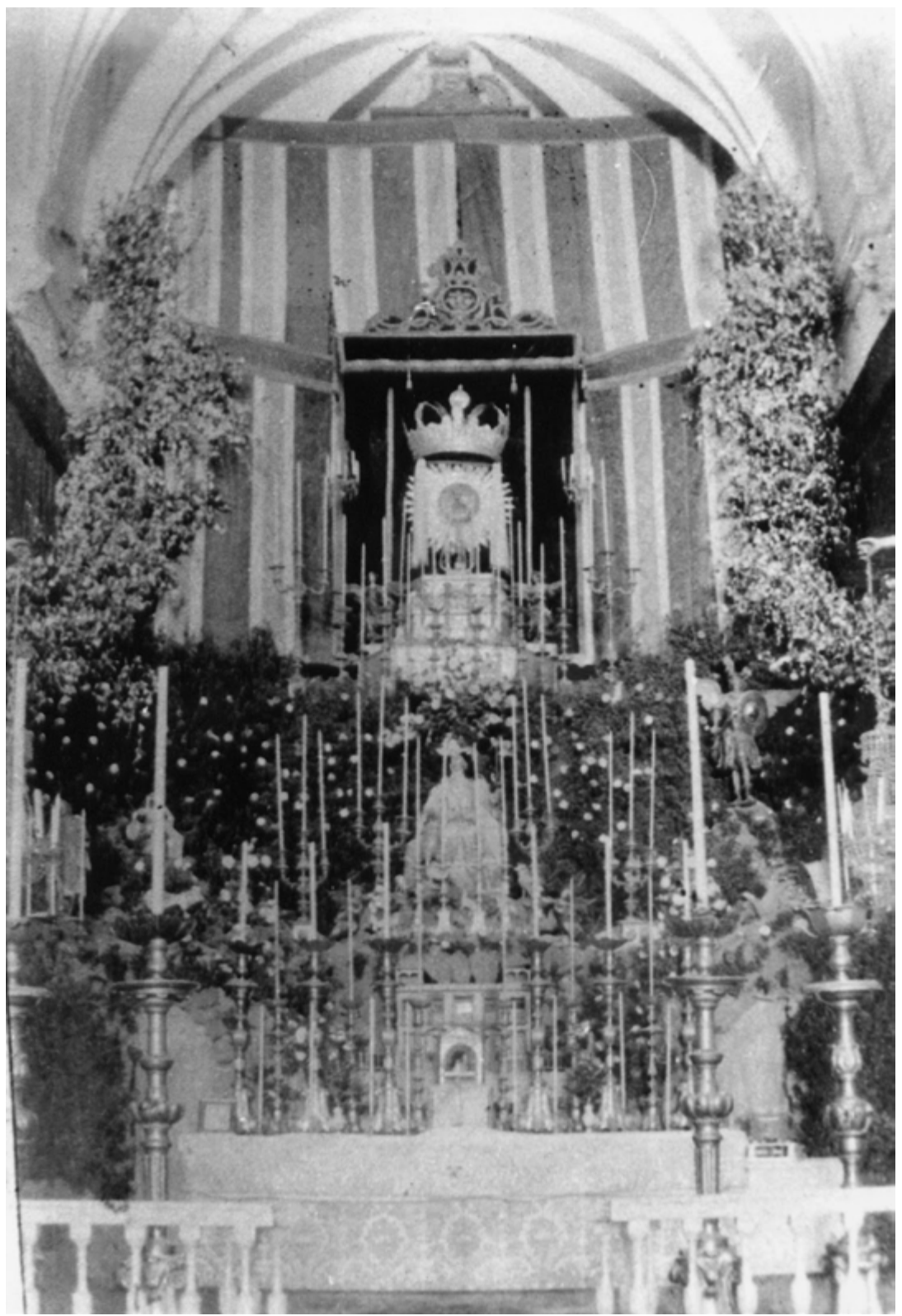

Figura 7. El risco de la Divina Pastora, principios del siglo XX, iglesia de Santa Marina, Sevilla. Foto: anónimo. 


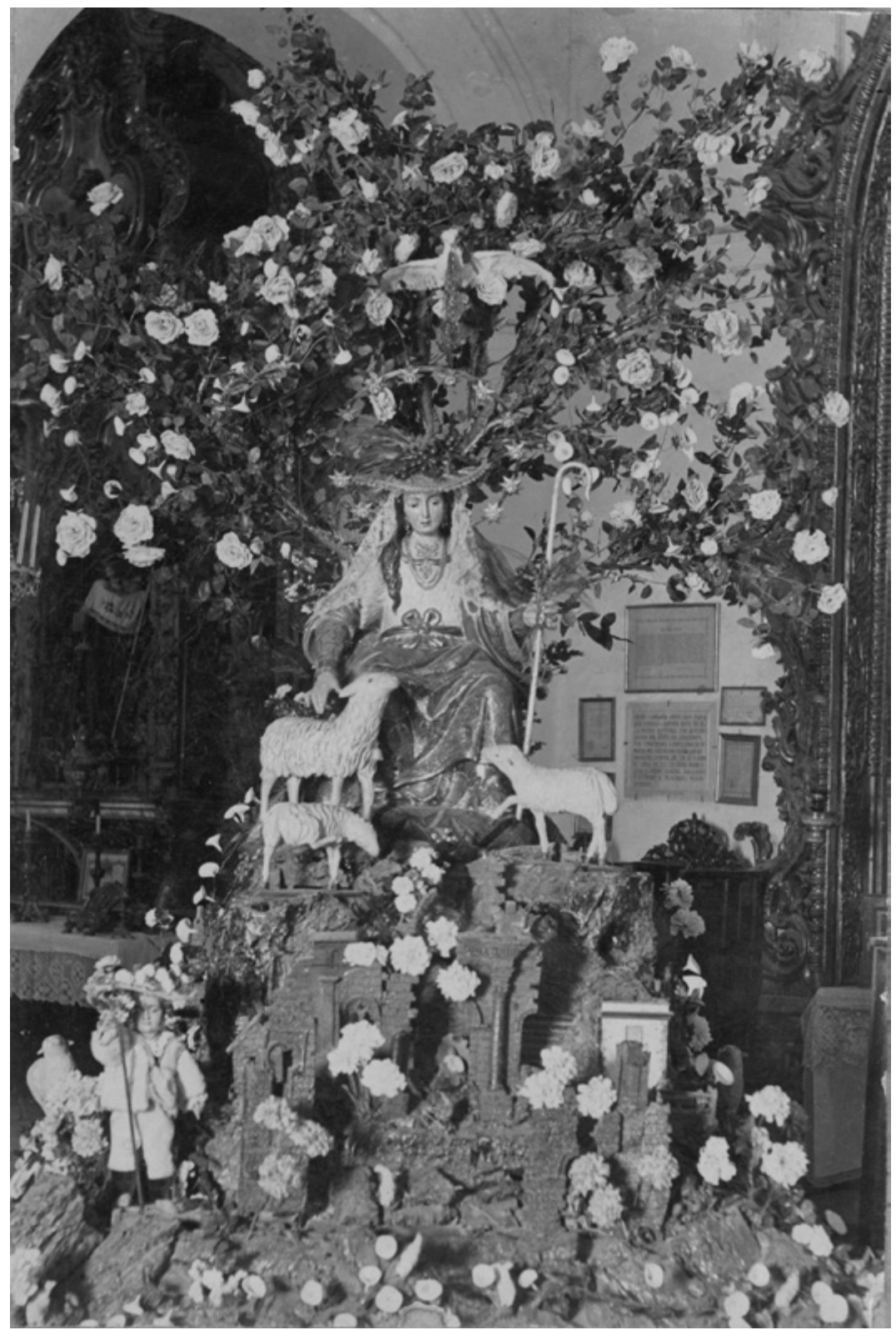

Figura 8. Anónimo, Divina Pastora de las Almas, primer cuarto del siglo XVIII, parroquia de Nuestra Señora de la Asunción, Cantillana (Sevilla). Foto: anónimo (hacia 1905). 